(C) 1984 ISIJ

\title{
小型誘導溶解炉中の溶鉄内の分散気泡の測定
}

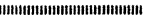

川上 正博*.富本 登*2. 北沢 康憲*3

奥山 優*4 ${ }^{*}$ 伊藤 公允 ${ }^{*}$

\section{Measurements of Dispersed Bubbles within Molten Iron Contained in a Small Induction Furnace}

Masahiro Kawakami, Noboru Tomimoto, Yasunori Kitazawa, Masaru OKUYAma, and Kōin Iтo

\section{1. 緒}

言

従来, 液体中に吹き込まれたガスからの気泡の生成機 構や平均気泡径等に関する研究は比較的多く行われてい るが(1)2)，溶鉄に関するものは, Iron and Guthrie ${ }^{3)} に$ よるノズル先端に拈ける発生気泡の大きさを調べたもの があるだけで，その分散形態については報告がない，本

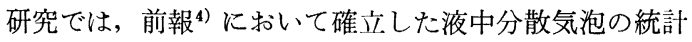
的処理法を溶鉄に適用し, 気泡頻度 $f(1 / \mathrm{s})$, ガスホー ルドアップ $H(-)$, 上昇速度 $v(\mathrm{~m} / \mathrm{s})$ を求め, 小型誘 導溶解炉内の鉄浴中への気泡の分散挙動を明らかにする ことを目的とした. 更に, 同一幾何学的形状の水浴を用 いた実験を行い，気泡の鉄浴および水浴中への分散挙動 の比較も行つた.

\section{2. 実 験 方 法}

用いた実験装置の概略を Fig. 1 に示す. 炉の寸法は 内径 $150 \mathrm{~mm}$, 深さ $400 \mathrm{~mm}$ である. 炉底部中央には, 内径 $1.5 \mathrm{~mm}$ のムライト製ノズルを埋め込んだ。炉の 上部には, 溶鉄飛沫の付着防止のため, ライニング加熱 用の黒鉛リングを埋め込んだ. 高周波電源には, 最高出 力 $36 \mathrm{~kW}$, 発振周波数 $2.2 \sim 3.1 \mathrm{kHz}$, サイリスタ制御 方式のものを用いた.この炉の中で, $20 \mathrm{~kg}$ の鋳物用銑 1 種 Bを溶解し, $\mathrm{N}_{2}$ ガスを $20 \mathrm{~N} l / \mathrm{min}$ の流量で吹き込 んだ.なお， $\mathrm{N}_{2}$ ガスを吹き込をないときの鉄浴深さは 190〜200 mm であつた.

電気探針は，2本の Mo 棒 $(\phi 1.5 \mathrm{~mm})$ に内径 1.5 $\mathrm{mm}$ のムライト製絶縁管をかぶせ, その先端を垂直方向 に $10 \mathrm{~mm}$ ずらして内径 $6 \mathrm{~mm}$ の石英管内に固定し, 更
に補強のために, 内径 $8 \mathrm{~mm}$ のステンレス管内に納めた 構造とした.この探針は, 炉体上部のアルミ製の枠に固 定した. また別に, 黒鉛棒を溶鉄中に浸漬した. Mo 棒 と黒鉛棒を直流電源に接続し， 2 組の電気回路を構成し た.この回路より得られる電気信号は, 前報4) 同様, ア ナログデータ・レコーダで記録し, マイクロコンピュー タで処理した.

測定温度は $1250^{\circ} \mathrm{C}$ である. また, 誘導摫汼の効果 を調べるために, 電源カット時の測定も行つた.この時 は, 一度 $1300^{\circ} \mathrm{C}$ まで昇温し, 電源をカットして $2 \mathrm{~min}$ 放置し，その後， $3 \mathrm{~min}$ 測定を行つた.この $5 \mathrm{~min} の$ 温度降下は約 $80^{\circ} \mathrm{C}$ であつた.

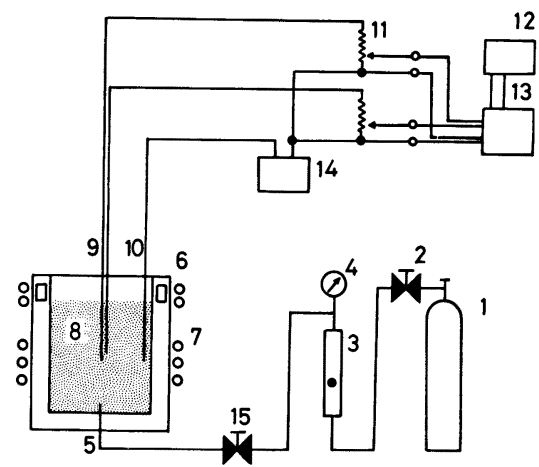

1 Nitrogen cylinder, 2 Reducing valve, 3 Float meter, 4 Pressure gauge, 5 Nozzle 6 Graphite ring, 7 Induction coil, 8 Bath, 9 Electroresistivity probe, 10 Counter electrode, 11 Variable resistor, 12 Oscilloscope,

13 Analog data recorder, 14 D.C. Voltage regulator,

15 Controlling valve

Fig. 1. Schematic diagram of the apparatus used to measure bubbles in molten iron.

昭和 57 年 4 月本会講演大会にて発表 昭和 58 年 5 月 23 日受付 (Received May 23, 1983)

* 豊橋技術科学大学: 工博 (Toyohashi University of Technology, 1-1 Aza-Hibarigaoka Tempaku-cho Toyohashi 440)

*2 豊橋技術科学大学大学院 (現: (株) 神戸製鋼所) (Graduate School, Toyohashi University of Technology, Now Kobe Steel, Ltd.)

*3 豊橋技術科学大学大学院 (Graduate School, Toyohashi University of Technology)

*4 豊橋技術科学大学(現：小山工業高等専門学校) 工博 (Toyohashi University of Technology, Now Oyama Technical College) 


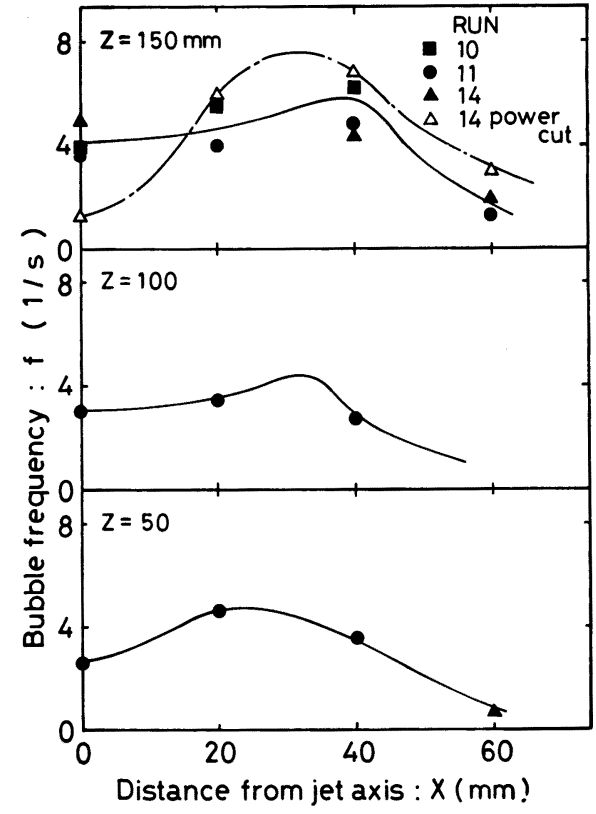

Fig. 2. Radial distribution of bubble frequency at different height, $Z$, from nozzle top in iron bath. Solid lines : power on, dotted line : power cut.

浴内の測定位置は，垂直方向は，ノズル先端からの高 さ $Z(\mathrm{~mm})$ で表し, 半径方向は, 中心軸からの距離 $X$ (mm) で表した.

水浴中の実験では，アクリル製円筒容器を用い，前 報4)と全く同じ操作で測定を行つた。な抏，ガス流量は $20 \mathrm{~N} l / \min$ である.

\section{3. 実験結果および考察}

\section{$3 \cdot 1$ 気泡頻度分布}

Fig. 2 に, 鉄浴中での測定結果を示す. 横軸にX，縦 軸には気泡頻度 $f$ を示した. 図より，（i） $f$ の水平方 向の分布は, 中心軸からずれた位置に最大值をもつ, (ii) $f$ は底から表面に昇るに従つて增加する, (iii) $Z$ $=50$ と深い位置でも， $X=60$ と比較的側壁に近い所ま で気泡が到達している，ことがわかる， $Z=150$ に示し た一点鎖線は, 電源カット時の測定結果で, 上記 項目 (i) の傾向がより強調されている.

Fig. 3 は, 水浴中での測定結果である.いずれの深さ でも, $f$ の水平方向の分布は, 中心軸上に最大值を持つ ており，2次元ガウス分布にのると見ることができる. 図中, おのおのの曲線に対する標準偏差 $\sigma$ の值を示し た. 鉄浴中の結果と比較すると, 気泡分散相の拡がり方 は小さく, 中心軸近傍での $f$ の值は大きい.

\section{$3 \cdot 2$ ガスホールドアップ}

鉄浴中のガスホールドアップの測定結果は，気泡頻度 分布について前述した 3 項目と同様の傾向を示した。

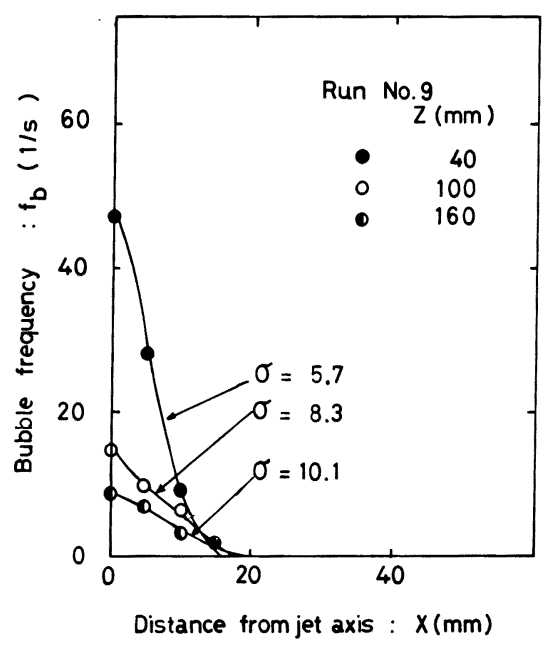

Fig. 3. Redial distribution of bubble frequency at different height, $Z$, from nozzle top in water bath. $\sigma$ is the standard deviation for Gaussian distribution curves at each height.

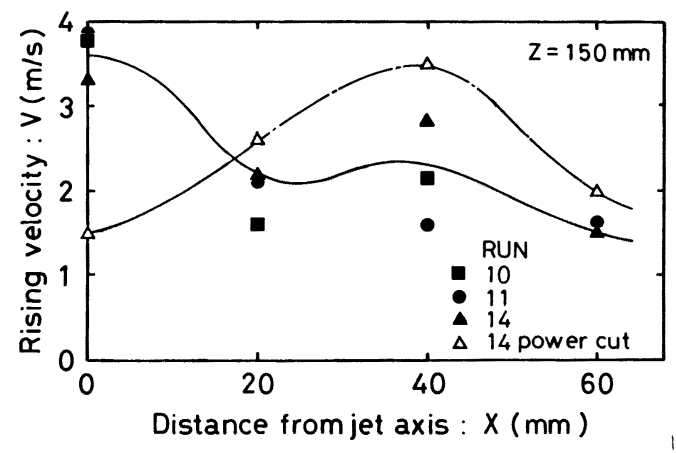

Fig. 4. Radial distribution of bubble rising velocities in iron bath.

た, 電源カットの効果についても同様, 極大值の偏心が より顕著に認められた。

\section{3 気泡上昇速度}

Fig. 4 に, 気泡上昇速度 $v$ の測定結果を示す. 図中 の一点鎖線は, 電源カット時の結果である. $v$ は $X=0$ の $1.5 \mathrm{~m} / \mathrm{s}$ から $X=40$ の $3.5 \mathrm{~m} / \mathrm{s}$ までいつたん上昇 し， $X>40$ で降下した. 電源オンの場合には， $X=40$ 付近のピークの他に， $X=0$ にもピークが認められた. $X=40$ にピークのあることは, 気泡頻度分布の傾向と一 致する. 電源オンの場合には, 誘導摫汼の効果により, 鉄浴中心部には強い溶鉄の上昇流が存在し, 側壁近傍で は下降流が存在する.このため, 電源オンの場合には, $X=0$ にピークが表れ, $X>20$ の所では, 電源カット時 にくらべ，vが小さくなつたと考えられる.

水浴中での結果は, $Z=150$ では, $v$ は, 中心で約 $1.5 \mathrm{~m} / \mathrm{s}$ の最大值をとり，X の増加とともに, 約 $1 \mathrm{~m} / \mathrm{s}$ まで減少することを示した. 鉄浴中の結果と比較する 


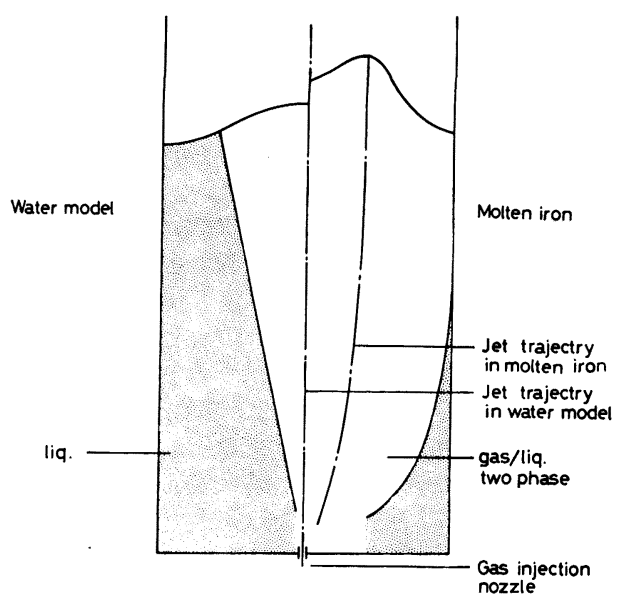

Fig. 5. Comparison of bubble dispersion zones. The left part shows the zone in water bath and the right, that in iron bath.

と, 全般に, $v$ は小さめの值であつた.

\section{4 気泡分散相の拡がりについて}

Fig. 5 の右半分に, 鉄浴中の気泡分散相の拡がりを示 した. 気泡分散相の境界は, $Z=50, X=60$ で気泡が検
知されたことから，定性的に定めた．図中の一点鎖線 は, 各深さでの $f$ のピークの軌跡を示す. $Z=150, x=$ 40 の位置に打汁る $120 \mathrm{~s}$ の $f$ のデータを一定時間間隔 で区切り，その間の $f$ の平均值を調べたところ，それは ほぼ周期的に増減していた。そのことから，一点鎖線を 中心軸とする気泡分散相が，約 $28 \mathrm{~s}$ の周期で旋回して いると考えられる.

Fig. 5 の左半分は，水浴中の気泡分散相を示す. $3 \cdot 1$ で求めた $\sigma$ を用い, $3 \sigma$ の軌跡より,気泡分散相の境界を 定めた．この境界と中心軸のなす角の 2 倍で定義される コーンアングルは $23.7^{\circ}$ であつた.

図の左右を比較すると, 気泡は, 水浴中では, 中心軸 からあまり拡がらず，密集して上昇するが, 鉄浴中では， 浴内のほぼ全域に払がつて上昇する，ことがわかつた。

\section{交献}

1) 森一美, 佐野正道: 学振 19 委-No. 10291 (昭和 55 年 9 月)

2 ) G. N. Oryall and J. K. Brimacombe: Metall. Trans., 7B (1976), p. 391

3 ) G. A. Irons and R. I. L. Guthrie: Metall. Trans., 9B (1978), p. 101

4 ) 川上正博, 富本 登, 伊藤公允：鉄と鋼，68 (1982), p. 774 


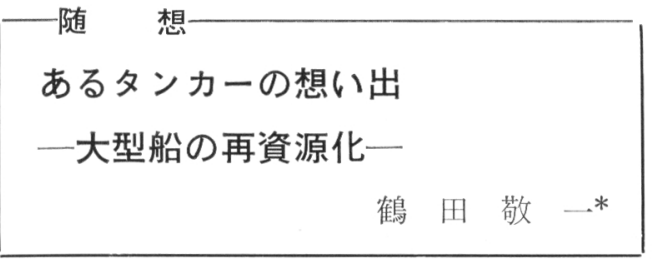

私は今, 静かに迫り来る宵闇の中で, 昔の想い出にろ けつている、穏やかな海である。私のすぐ隣りには，半 分解体されかけている VLCG が，繋船されている。私 も, 今日この船舶解撤場の岸壁に曳航されて来て, 接岸 されたところなのである．静かな夜のとばりが下りて来 る中で, 数々のまたいろいろな想い出が, 浮かんでは消 えていく.今は, 燈り一つ点いていないこの船の上で, 多勢の人達が，生き生きと動きまわり，私を生又出し， そして世界経済のために原油を運び，私も一生懸命，全 機能を発揮して頙張つた時代，それも今終わりを告げよ らとしている，それらのことを，振り返つてみるのに， ちようど良い夜である。

私は昭和 48 年の初め, 造船ブーム, タンカーブーム で多忙を極めていた，ある日本の造船所の中で，生まれ た．その頃流行であらた，VLCG の1隻として，前の 年に起工された。 その頃は，日本いや世界の景気上昇は すざ本じい勢いで，伸びて扣り，それを支光るェネルギ 一源の一つとして, 石油 (原油) が, 中近東から世界各 地飞輸送され, 第 2 次, 第 3 次製品を生又出し, 关の代 わりに，建設，掘削材料がまた中近東に運ばれる等，海 上の物流が，世界の景気伸長の，原動力となつていた時 代なのである。

私は，その時代の最も新鋭なタンカーとして，設計 . 建造された一隻である。優秀な機器も整備され，新しい 航海計器も積まれたそそして少しでも多くの油が積める よらに，日本の優れた製鋼技術が生九だ，高抗張力鋼が 甲板，船底等の大切な個所に，随所に使わ机ている。こ こで私のことを少し紹介すると, 体格は, 長さが $315 \mathrm{~m}$, 幅が $55 \mathrm{~m}$ ，深さが $20 \mathrm{~m}$ である. 3 万 6 千馬力のター ビン機関を積んで, 約 16 , 片速力で走ることがで さる.体重が約 4 万トンで, 約 26 万トンの油を積むこ とができる. 体重 4 万トンのらち, 鋼材が約 3 万 4 千卜 ンを占め, 更にそのらち8千トンが，八イテンである. ちようどその頃は, 造船所は建造ブームで, 次から次へ
と, 新しい船が建造されては, 引き渡されていつた。

私もその工場のシリーズ船の 1 隻として, 起工から完 成まで，約 10 ヶ月といら短い期間で建造された．以前 は起工から進水までが 5〜6 ケ月, 進水後も7〜8 ヶ月か かり，1 年以内に船がでさるのは難しかつたが，造船工 場の大型化, 起重機の大容量化に伴い, 大きなブロック で建造する方法が採用され，またパイプ等の艤装品も， ブロックの中に組久込まれるというような, 新工法の採 用でどんどん船の建造期間が，短縮され，新しい船が， 続々と海に浮かんでいつた.

私の場合も, 多勢の人達が夜遅くまで, また日曜日も 返上して，働いていたよらである.しかし仕事は非常に 丁寧に, 親切にやつてくれたと感謝している. 進水する と造船所の岸壁につながれて, 艤装工事が始まつた。乗 組員の寝泊束りする居住区, 推進機械や発電機の据党つ けてある機関室, 油移動のための専用ポンプ室, 船の操 縦室等, 至る処にパイプがつながれ, 電線が引かれ, 機 器が取り付けられていつた. これらの工事が一応完了す ると, 船主や関係者が, 多勢乗り組んで, 船の性能確認, でき栄えを調べるために, 海上運転が行われた。 2 泊 3 日にわたり, 入念に, 速力, 燃料消費, 機器能力, 操縦 性と種々なテストが行われた。このテスト結果の不具合 個所を, 直して, 拈化粧をして私は完成され, 命名式を 迎克た。

あの晴れやかな命名式の様子は, 今でも眼に焼き付い ている. 船名は紅白の幕で隠され, 船室ブリッジの前に は, 薬玉が下げられ, その前に多勢のお客様が, 勢揃い して列んでいた。来賓の挨拶が終わつた後に，船主のお 孫さんの㧤さんが, 私の名前を大きな声で叫んで, 薬 玉に結んである紐を，斧で思い切り切断した。 その途端 薬玉が割れて, 五色の紙吹雪が飛び, 風船が空に舞い上 がり, 船名を隠していた幕がはね上がり, たくさんの鳩 が飛び立つていつた，扣客様及び，見物の従業員の全員 の, 大きな拍手の中で, 私はVLCGとして, 誕生した のである。

私が就航してから約 3 年間は, 本当に順調であつた。 造船所の人達が, 一生懸命作つて, 整備してくれたため か, ぞんなに一生懸命働いても, 身体のどこにも傷みを 感じることもなく, 船長, 機関長の命令どおりに動くこと ができ，主として中近東から，日本の間をピストン方式 で,たくさんの油を運搬した. 乗組みの人達も陽気で, 居

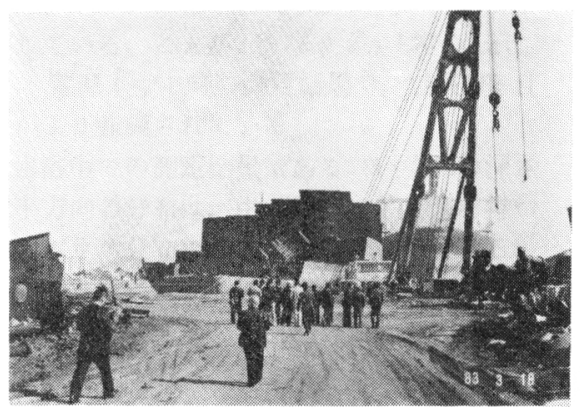

写真 1 接岸されたタンカーと半分解体された船体

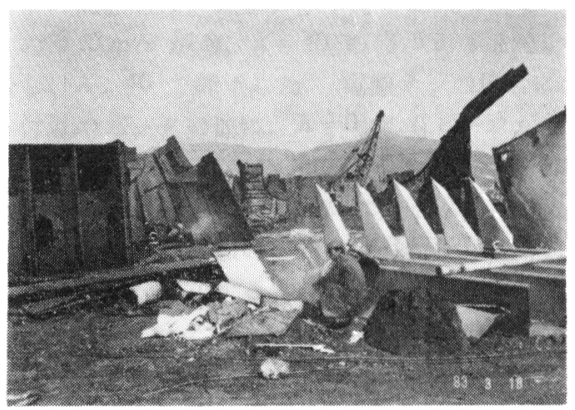

写真 2 解体作業状況

* 日本鋼管 $($ 株) 
住区，機関室とも和やかな雾囲気で，西時は飛び魚と 競争したり，いるかと話をしながら，楽しい航海を続け た。もちろん, 海は静かな時ばかりはなく, 嵐の時もあ つたが, 船長が上手に蛇を取つてくれ, 全員で頑張り協 力しながら無事航海を続けた。

しかし, 中東で起こつた戦火は鎮まらず, 拡大を続け, それが石油の生産低下，価格の值上りにつながり，世界 中でエネルギー消費の節約が叫ばれ，いわゆる“オイル ショック”により，その省エネ運動が軌道に乗り，石油 の需要が減少し始めて来た。 その結果として, 石油の荷 動きが減り, それにつれて, 吾々の活動も少しづつ, 動 きが鈍つて来た．私も力一杯走らずに，できる限り，楽 にエネルギーを最小に使つて, 航海するといら方法を採 るよらになつたが, 一方, 造船所ではまだタンカーを建 造中のものも市り，仲間は増觉て米る傾向にあり，之ら とらタンカー船腹が過剩になり, 運賃が下がり, 運航採 算がとれない状態になつて来た， そのため，特に大型で 効率の覀い船から，仕事から外されるよらになつて来 た. 仕事から外された船は, 古い船はスクラップにされ, 比較的新しい船は, 各地で熬船されるようになつて来 た．私は幸いにして，その時点では荷主との長期契約の ため，何とか生き延びることができたが，蒸気タービン といら，大きな胃袋を持つているために，厄介な荷物で 西つたことと思う。笛のためとうとら昭和 55 年春, 他 の仲間とともに繋船されることになつた。 しかし, 私達 を海上で（湾内で）繫船しておくのも，非常にたくさん の費用がかかる. 吾々の体内に設置されている機械類 は，長い期間使わないでいると，動かなくなつてしまら ものもあるからである。そのために, 一定期間ごとに確 認運転をしたり, 海上の湿気, 塩分で腐食しないように, 特殊ガスを封入したり, 盗難, 暴風時対策等, 莫大な費 用になる。しかもこの慗船が 1 年とか 2 年とか，再度使 用寸る目的のある時は良いのだが，景気の回復の見通し がたたず，先行きがわからない状態では，長期に続ける わけにはいかない。 また一方, 技術的な面でも海上污染 防止のための, 装置の装備が義務ゔけれるようになり， 吾々が再度働くためには, 大きな改造をする必要も出て 来た. これらのことを判断して，今後の負担を軽減玄る ために，処分されていく仲間が増劣て来た．えして今， 私がその運命をたどろうとしているのである。

今まで解体された船の鋼材は, ほとんど伸鉄材として， 製鋼所に送られ，新しい建材等として，生れ代わつて世
の中のために尽くしているし，機械，モータ一類は，良 く選別されて再使用されているよらである。

しかし私はまだ 10 才，まだ老いるには早く，使い力 によつては，十分に役立つはずだ.すぐにスクラップに しないで，役に立つ方法はないのだろらか，私を一生眯 命, 建造してくれた造船所の人達, 長い間可愛がつて使 つてくれた乗組員の努力之，苦学を考光ると，何か，感 無量といらところである. 今隣りに横たわる, 半分削り 取られたような友人を見て，思わず悲しくなつてしまら 私です。明日からは，多勢の人達があた私の中で働くで あろら。しかし今度は私を作るためでなく, 葬り去るた めに，働くのだ.

以上あるタンカーの想い出を，書き述べたが，最後に， 彼女（船は女性なのである）が，もつと扮役に立つ方法 は，ないだろらかと，心から叫んでいた。大型タンカー の再利用方法を, 過去の例, 父の他から考光てみよう。

(1) 洋上備蓄タンカー

船の形も変えず，手も加えずにすぐに利用でさる，原 油または石油の一時保管タンクとして，利用する方法で あるが，陸上タンク方式に比べ，維持，管理に費用がか かり，特に陸上のタンク容積が，不足の時のみに使用さ れる力法。

（2）清水輸送タンカー

世界各地で, 真水の不足している地域が多く, 商売に はなるよらであるが，古いタンカーの洗浄，または改造 費も必要. しかし一番の問題は, 清水の荷役設備がなく, 大型のタンカーは利用できないであろら、沖どり方式等 を考光れば可能性もあるが費用がかかり，当分先のこと になる。

（3）浮遊式石油生産設備への改造

世界の海洋油田も, 浅くて小規模な油田は, 生産設備 も移動式の方が，効率が良い場合が多い。タンカーに油 ガス分離装置等の原油精製設備を設置して, 生産設備兼 ストレージタンカー, 兼ローディングポンプステーショ ンとしての機能を持たせ, 油田上にアンカーまたは他の 万法で繋留する方法.

繋留方法, 油の汲み上げ方法等, まだ開発をしなけれ ばならない項目も多いが, 結構有望な使い方であると思 う。しかし VLCG，ULCGの利用はどらか，せいぜい 12〜15 万トン程度のタンカーで十分でないか. しかし 現在世界各地で真剣に，検討されている方法である.

（4）大型バージへの改造

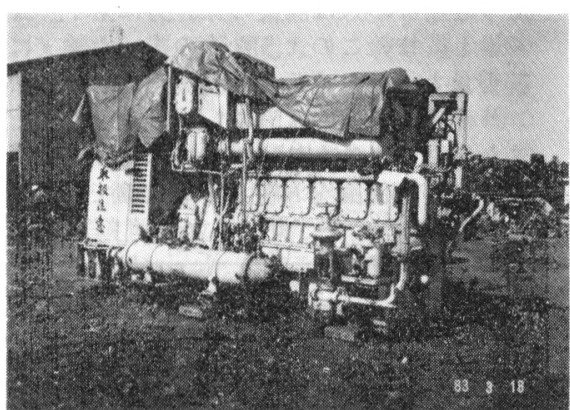

写真 3 出荷前の取り外された発電機

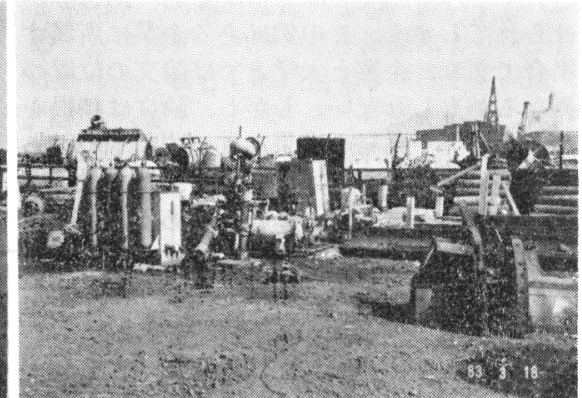

写真 4 取り外し部材整理状況（ボンべ，タンク等） 
現タンカーの荷艙部分を，平面的にスライスして，大 型の浮遊バージに改造する方法.

改造されたバージの使い途は，海上作業台，運搬船， プラントバージの台船等利用範囲も広く, 案外有望な用 途と思われる.

(5) 船殼構造材の利用

タンカーはたくさんの支切り壁で構成されている.こ の壁とその補強材を上手に利用して，岸壁護岸用の，埋 立て仕切り壁，人工島の構造の一部等に利用する.この
方法は相手の構造，工法が上手に適合しないと難しく期 待は少ない。

これらの方法は, いずれも理論上可能なものであるが これだけでは, 現在繫船中のタンカーをすべて, 利用す ることもできず, 大きな課題である.

いずれにしても，有限であり，貴重な資源である鋼の 再資源化は吾々に与えられた大きな使命であり，今後共 大いに研究をしていきたいと考えている.

\begin{tabular}{|c|c|}
\hline 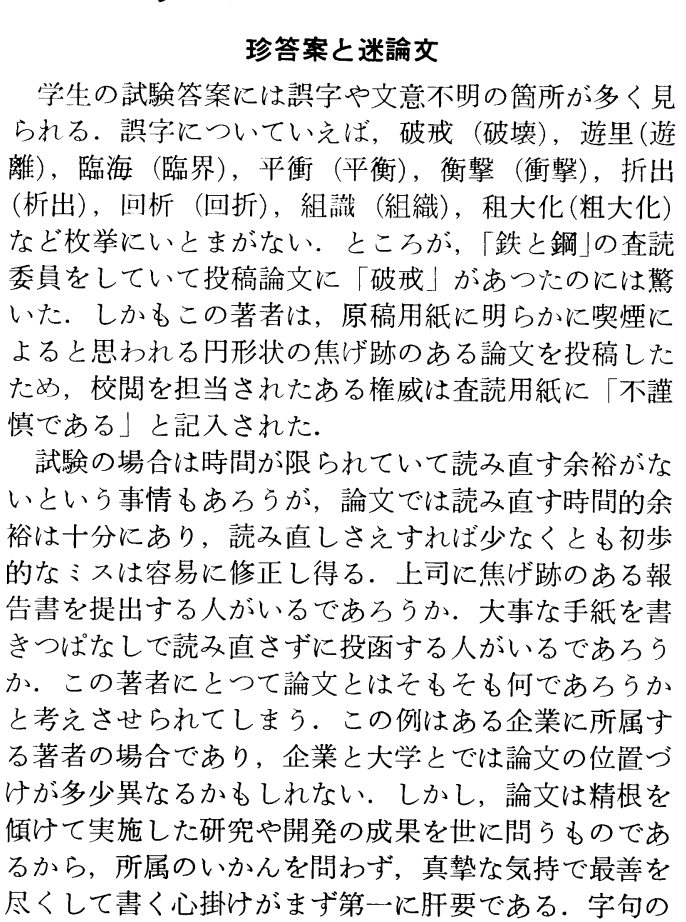 & 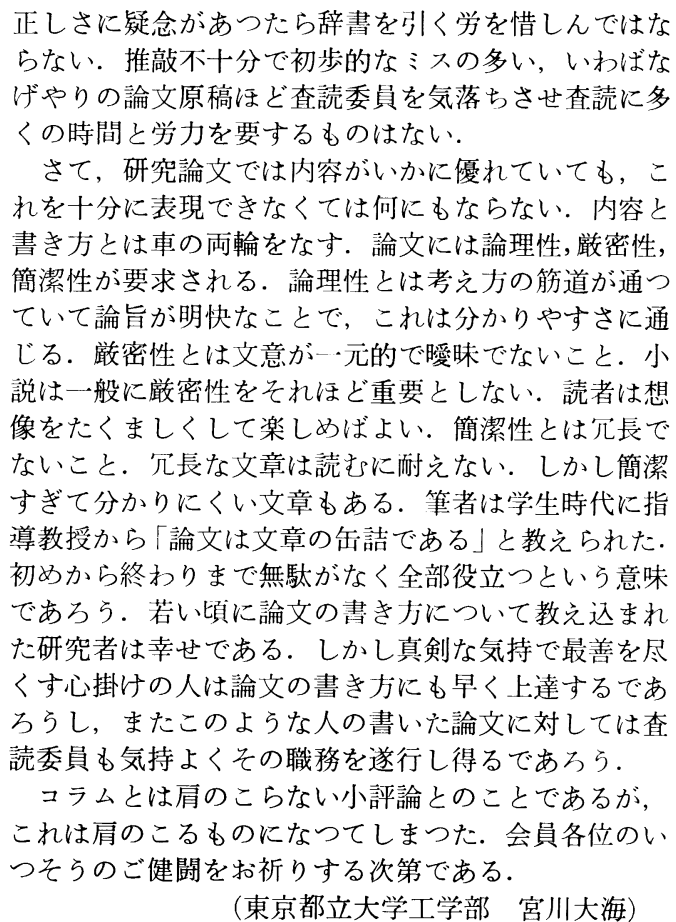 \\
\hline
\end{tabular}




随
イラクから “想—Inhibition of Reoxi-
dation of Direct Reduced Iron”
投稿のいきさつ

開戦以来すでに 3 年半になろらとしているが, 現在な おイランとの交戦状態が続いているイラクの Dr. Jaleel Kareem Ahmed からの投稿 Report “Inhibition of Reoxidation of Direct Reduced Iron”† が編集委員会 の審査を通過し, 欧文誌への掲載が決定されたことは, 博士から投稿の依頼を受け, 仲介の役割を果たした私と しては非常に嬉しい。この機会に，投稿の背景など私が 知つている範聿で今までのいささつを記して読者の御参 考に供したい。

彼と私との出会いは，昭和 55 年 7 月に，私が国際協 力事業団からイラク共和国へ治金関係の専門家として 2 年間の予定で派遣され, 首都バグダッドにある Specialized Institute for Engineering Industries (略称 SIEI) に配属された時に始まる.

SIEI の本部はバグダッド市内の繁華街にあつたが， 近郊の Dora (Fig. 1 参照) に移転中であり, 実験棟之 試作工場は当時すでに完成して移転を終わつていた，彼 と私とはこの研究所の生産技術部に属し, 試作工場の一 隅に設けられた臨時の事務室に机を並べていた.

イラクは社会主義体制の国であるので, 主要な企業は 全部国営であり, 工業鉱物資源省 (Ministry of Industries and Minerals) の下に工業局 (State Organization for Engineering Industries) があり, 当時国営 9 企 業がそのさん下にあつた. SIEI はこれらの企業の技術 を側面から指導する立場にあり, 昭和 48 年国連の協力 のもとに活動を始めた。 これらの企業の一つが Basrah の Khor Al-Zubair にある State Enterprise for Iron and Steel Industry で，ここでは 1978 年に HyL 法 による還元鉄の製造設備が完成し稼動を開始したが1), 製品の在庫が増加したために化学を専攻した彼に再酸化 防止対策の研究が課せられたよらである.

私の仕事の範囲は, 球状黑鉛鋳鉄の製造, 中子造型方 法の合理化のほか, 前任者で大同特殊鋼 (株)から出向の 堀越弘彦氏の指導されていた鋼の熱処理技術を継続して 担当することになつていたので, 彼とは仕事上直接の関 係はなかつた，しかし，赴任後間もなく，彼は還元鉄の 再酸化防止対策として“Wax Process”を研究中である と話しかけてきた．私はワックスは石油精製の副産物で もあり, それは非常に興味のある研究であると思うと答 えたところ,彼は数日後実験中の現場を案内してくれた。 Dora には適当な試験設備がなかつたので，この実験は $50 \mathrm{~km}$ ほど南の Iskandariyah にある State Enterprise for Mechanical Industries の鋳造工場の一隅で行われ ていた，8月の $40^{\circ} \mathrm{C}$ 前後の猛暑のなかで, 彼は玉のよ らな汗をぬぐいながらドラム年の中でワックスを溶かし

$\dagger$ Trans. ISIJ 24 (1984) No. 2 亿揭載

* 国際協力事業団工博

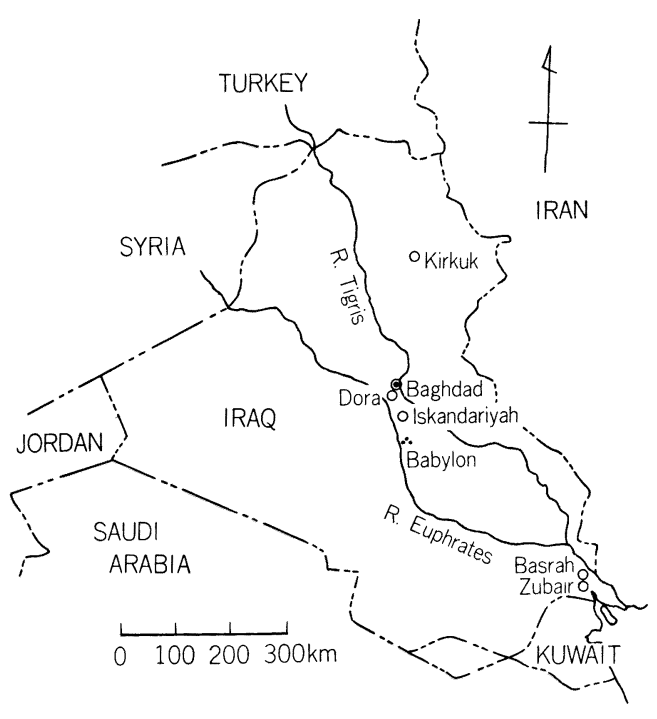

Fig. 1. Map of Iraq

ていた. 助手の若い女性の化学者がワックスの温度を測 つていた. 研究所も工場もこの研究に対して理解がな く，作業員を出してくれないので困るとこぼしていた.

しかし，彼はこれは“Japanese Process”であると宣伝 して研究を推進しているといらことであつた．たぶん日 本の技術者の推せんする方法であるということで権威つ けて研究を進みやすくしているように思われた：還元鉄 溶解用の高周波実験炬はまだ据付けてなかつた。私は今 後の実験の進め方について若干の助言をして, 彼を励ま してやつた.

彼は Iskandariyah からさらに $40 \mathrm{~km}$ ほど南の有名 な遺跡 Babylon の近くに住み，バスで研究所まで通つ ていたが， 7 時 30 分の始業時間前にいつも出勤してい た. 彼の経歴についてはよく知らないが，日本には昭和 46 年に行つたことがあり, 新潟の日本がス化学(株)に 6 か月ほどいたとのことで，そのためか日本に対して非常 に親近感を持ち，この研究が完成したら日本の然るべき 学会でぜひ発表したいとのことであつたので，私はさつ そく鉄鋼協会に昭和 56 年度の講演大会の開催場所や期 間を問い合わせた。

しかし, 昭和 55 年 9 月 22 日にぼつ発したイラクに よるイランの軍事基地の爆撃, 続いて翌 23 日のイラン によるバグダッド等の報復爆撃により両国は戦争状態に はいつた．私ども国際協力事業団から派遣されていた専 門家は当時イラクに7名いたが，安心して技術協力でき るよらな状態ではなくなつたので，10月6日タクシー でバグダッドを脱出し，砂漠を約 $1000 \mathrm{~km}$ 横断して隣 国ヨルダンの首都アンマンにたどりつき，ここから飛行 機で帰国した。

彼は私にぜひ Basrah の還元鉄工場を案内したいが， 少し涼しくなつてからの方がよいといらことで延期して いたため，私はついにこの工場を見学する機会を失つて しまつた。

その後イラクとの音信が途絶えていたが，昭和 56 年 
12 月に彼から手紙が届き, Wax Process がイラクで特 許登録された, ついては日本の学会で発表したいという 主旨であつたので，私は講演大会の開催予定等を調べて 返事をした。しかし，翌 57 年 4 月になつて，学会には 出席できないが，投稿だけでもしたいと 4 ページほどの 手書きの原稿を送つてきたので, 私はさつそく協会に投 稿の手続きをした。

編集委員会で審査された結果, 原稿の内容に不備な点 があり補足修正してほしいとの連絡があつたので, 昭和 57 年 8 月に彼にこの旨通知したが, 彼からは何の返事も 来ない. その理由は不明であるが, 彼の投稿の意志は変 わらないものと考光, 編集委員会の判断に基づき, 彼の
返事を待つことなく，若下の修正をすることで欧文誌揭 載が決定された。

私としては, イラクでの 3 か月の生活は, 覚悟はして 行つたものの, 猛暑の最中で, 専門家の受入れ態勢の不 備なども手伝つて，苦しいことばかりの連続で，あまり よい印象は残つていない。しかし，その中にあつて，彼 の友情はいつも私を琞気つけてくれた。遙かに彼の健在 を祈つて筆を扰く。

\section{文献}

1）鉄鋼便覧第 II 卷（日本鉄鋼協会編）(1980), p. 332 [丸善]
(294 ページより)

\section{$3 \% \mathrm{Ni}$ Gr Mo V 低圧タービンディスク鋼の破壊靫} 性に及ぼす温度, 試験片寸法および形状の影響

(N. B. Shaw and G. M. Spink: Metall. Trans., 14A (1983) 4, pp. 751〜759)

低圧タービンディスクの安全性を評価するために，破 壊鞋性とその解析方法について研究した. $3 \% \mathrm{Ni} \mathrm{Gr} \mathrm{Mo}$ $\mathrm{V}$ 鋼について $-100 \sim 100^{\circ} \mathrm{C}$ の温度で破壊靱性試験を行 つた. 試験片は 12.5 100 mm 厚のコンパクトテンショ ン (CT) 試験片と片側切り欠き曲げ試験片および半 円 板型曲げ試験片である.

破壊靬性は遷移温度まで試験温度の上昇とともに増加 する。この遷移温度は安定延性き裂の進展開始温度と一 致していた。遷移温度以下の温度では破壊は線型弾性末 たは弾塑性破壊力学によつて解析することができる。遷 移温度以上の温度では破壊は塑性崩壊 (plastic collapse) によつて起こつた。

遷移温度は試験片が小さくなると，しだいに低下す る.そして試験片厚さが同じであれば曲げ試験片より
CT 試験片によつて得られた遷移温度のほうが低い. 遷移温度領域では小型試験片でフルサイズの構成部品の 破壊挙動を予測することはできない，遷移温度以下の温 度ではデータは非常にばらついて，3倍にも達すること があつた。

試験片はできる限り大きなものを用いるべきであり， もし破壊が安定延性き裂の進展なしにへき開によつて起 こる場合には，より大きい構成部品の挙動は予測でき る. 遷移温度以下の温度範囲で概略の破壊靶性值を推定 するのは或る温度で試験し, 他の研究者のデータも用い てここで数式化した規準曲線を用いれば可能である。も し材料が少なければシャルピー破面遷移温度から $K_{\mathrm{IC}}$ の下限界を推定できる.ただしこの場合は過度に小さく 評価することになる．破壊が塑性崩壊で起こる場合には 構成部品が同じ温度で同様の形態で破損することを示す ことができないかぎり，フルスケールの構成部品の破壊 は予測できない。

(安中 嵩) 